\title{
Дунаєв Б. Б.
}

кандидат технічних наук, старший науковий співробітник відділу координації бюджетно-податкової та грошово-кредитної політики НДФІ ДННУ“ААадемія фінансового управління", Київ, Україна,bbdunaev@ukr.net ORCID ID: https://orcid.org/0000-0003-2925-0276

\section{ВИХІД ЕКОНОМІКИ КРАЇНИ ЗІ СПАДУ НА СТАБІЛЬНЕ ЗРОСТАННЯ}

\begin{abstract}
Анотація. Починаючи з 2008 р., економіки високорозвинутих країн не могли вийти з бінансової кризи, перебували в стані депресії $і$ балансували на межі дебляиії. Ця ситуація збіглася у 2020 р. зі спадом реального валового внутрішнього продукту (ВВП) у світовому масштабі через пандемію COVID-19. Стан економіки в Украӥні вимагае пошуку шляхів та інструментів виходу в умовах скорочення чисельності населення, негативного виливу зовнішніх чинників. Зростання національної економіки стримується податковим навантаженням, зовнішніми боргами і недостатніми інвестиціями у виробничий капітал. Аля забезпечення стабільного розвитку необхідне державне регулювання розширеного відтворення капіталу, який є $і$ працює у сфері виробництва. При розширеному відтворенні капіталу інфляиійне саморегулювання ринкової рівноваги через систему грошового обігу центрального банку і ставка податку на дохід виробництва, не більша від оптимальної, забезпечать постійне зростання реального ВВП. Аосягнення мети виходу зі спаду з подальшим стабільним зростанням ВВП можливе за державноі політики, що трунтується на фундаментальних законах економіки і правах приватної власності.
\end{abstract}

К $\Lambda$ юч ов і с $\Lambda$ ов а : економіка, ринок, попит, пропозиція, праця, капітац, гроші, віАтворення, інвестиції, амортизація, інфцяція, криза.

Форм. 45. Табц. 2. Аіт. 17.

\section{Boris Dunaev}

Ph. D. (Technical), SESE "The Academy of Financial Management",

Kyiv, Ukraine, bbdunaev@ukr.net

ORCID ID: http://orcid.org/0000-0003-2925-0276

\section{RECOVERY OF THE COUNTRY'S ECONOMY FROM RECESSION TO STABLE GROWTH}

\begin{abstract}
Since 2008 the economies of highly developed countries have not been able to get out of the financial crisis in twelve years, and have been in a state of depression and teetered on the brink of deflation. This crisis coincided in 2020 with the onset of the global recession in real gross domestic product (GDP) caused by the Covid-19 pandemic. The state of the economy in Ukraine requires looking for ways and tools to overcome the crisis in the decline in GDP in the face of population decline and the ongoing global crisis. The growth of the Ukrainian economy is constrained by the tax burden, external debt and insufficient investment in productive capital. To ensure the stable development of the country's economy, government regulation of the expanded reproduction of capital, which is available and which works in the manufacturing sector, is necessary. The main source of investment in the manufacturing sector is depreciation deductions from capital involved in production. With investments that are less than depreciation, only a narrowed reproduction of capital is possible, that is, capital is consumed. Anyone who uses depreciation deductions for other purposes destroys their own production. Investments in excess of depreciation charges are possible if there is a net investment. The government should regulate net investment at the rate of net income through incentive taxation.
\end{abstract}

(C) Аунаєв Б. Б., 2021 
The capital that operates in the manufacturing sector can be regulated by the coefficient of consumer demand through existing incentives. With expanded reproduction of capital, inflationary self-regulation of market equilibrium through the central bank's money circulation system and the rate of tax on production income, which is not more than the optimal rate, ensure constant growth of real GDP. Achieving the goal of overcoming the recession with the subsequent stable growth of GDP is possible with a state policy based on the current laws of the economy and private property rights.

Keywords: economy, market, demand, supply, labor, capital, money, reproduction, investment, depreciation, inflation, crisis.

JEL classification: E44, E52, H58, H60.

\title{
Дунаев Б. Б. \\ кандидат технических наук, старший научный сотрудник отдела координации бюджетно-налоговой и денежно-кредитной политики НИФИ ГУНУ “Академия финансового управления", Киев, Украина \\ ВЫХОД ЭКОНОМИКИ СТРАНЫ ИЗ СПАДА НА СТАБИЛЬНЫЙ РОСТ
}

\begin{abstract}
Аннотация. Начиная с 2008 г., экономики высокоразвитых стран не могли выйти из финансового кризиса, находились в состоянии депрессии и балансировали на грани дефляции. Эта ситуачия совпала в 2020 г. со спадом реального валового внутреннего продукта (ВВП) в мировом масштабе из-за пандемии COVID-19. Состояние экономики в Украине требует поиска путей и инструментов выхода в условиях сокращения численности населения, негативного воздействия внешних факторов. Рост национальной экономики сдерживается налоговой нагрузкой, внешними долгами и недостаточными инвестициями в производственный капитал. Аля обеспечения стабильного развития необходимо государственное регулирование расширенного воспроизводства капитала, который существует и работает в сбере производства. При расширенном воспроизводстве капитала инбляционное саморегулирование рыночного равновесия через систему денежного обращения центрального банка и ставка налога на доход производства, не большая, чем оптимальная, обеспечат постоянный рост реального ВВП. Аостижение цели выхода из спада с последующим стабильным ростом ВВП возможно при государственной политике, основанной на фундаментальных законах экономики и правах частной собственности.
\end{abstract}

К $\Lambda$ ючевы е с $л$ в а : экономика, рынок, спрос, преАложение, труА, капитац, Аеньги, воспроизводство, инвестиции, амортизация, инфАяция, кризис.

Економічне становище у світі визначається світовою системною фінансово-економічною кризою, що фактично триває з 2008 р., з якою збіглася у 2020 р. криза, пов'язана з пандемією COVID-19. Економіки високорозвинутих країн не змогли за 12 років остаточно вийти з фінансової кризи, перебували в стані депресії і балансували на межі дефцяції, оскільки істотно завищили вартість створених ними активів фінансового сектору, який з кінця 1980-х років став основним Ажерелом збільшення факторів виробництва і зростання валового внутрішнього продукту (ВВП) [1-4].

Вся історія капітаАізму супроводжується цикАічними структурними кризами, що зумовили створення нової економічної моделі збільшення факторів виробництва [5]. Відомі мануфактурний капіталізм, фабрично-заводський акціонерний капіталізм, монополістичний капіталізм і “змішана економіка" [4]. ПіА час структурної кризи 1930-х років, коли економіка США зазнала 
Аефмяції і ставка процента перебувала на нульовій позначці, у 1933-1934 рр. уряд президента Ф. А. Рузвельта девальвував долар на 40 \% щодо золота через скуповування останнього і випуск паперових грошей. Аевальвація і швидке зростання кількості обігових коштів міквідували дефмяцію. У 1934 р. у США віАбувалося стабільне зростання економіки, інфцяція становила 3,4 \% (після Аефмяції в 1932 р. 10,3 \% і в 1933 р. 5,1 \%) [6]. За "Аержави добробуту" змішаної економіки у промислово розвинутих країнах на початку 1970-х років виникла стагфмяція при нормі капіталовкцадень у виробництво близько $30 \%$ ВВП. ААя подаАьшого зростання виробництва використовуваних природних ресурсів стало недостатньо. Витратна модель, що вимагала постійного нарощування ресурсної бази віАтворення економіки, досягла межі. В економіці США наприкінці 1970-х років знайшли вихіА зі стагфмяції через піАвищення Ао 20 \% ставки процента Федеральної резервної системи (ФРС) з оАночасним зниженням податків. Рівень безробіття протягом Авох років реформ піАнявся Ао 10,2 \% за інфмяції 6-8 \%. Але ці заходи призвели в розвинутих країнах Ао скорочення податкових наАходжень Ао бюАжету і спричинили зростання його дефіциту, який необхідно було покривати за рахунок запозичень і збільшення Аержавних боргів. Країни, що розвиваються, і слаборозвинуті країни внасліАок різкого піАвищення ставки процента за креАитами виявилися не в змозі обслуговувати борги, необхідні були нові запозичення Аця виплати процентів. Виникца світова тенденція економічного зростання за рахунок збільшення Аержавних боргів, яка забезпечувацася фінансовою експансією розвинутих країн у країни, що розвиваються, і слаборозвинуті країни. У 1976-1979 рр. у державах Заходу намітилося економічне піднесення з темпами 2,4 \% на рік. Але в 1980-1981 рр. у результаті кризи перевиробництва реальний ВВП у розвинутих країнах скоротився на 7-8 \%, виявивши тривацу тенденцію перенакопичення виробничого капіталу. 3 метою виходу з кризи буАо ввеАено новий міжнародний неоліберальний монетарний режим, що обмежив регулюючу роль Аержави в економіці й звільнів ринки віА ії контролю [4]. Зросла потреба країн у кредитах Аля інвестицій і виплат з обслуговування боргів, які забезпечували збереження соціальної стабільності. ВіАбувалося стрімке збільшення активів спекуцятивного світового фінансового сектору. Ринки облігацій і боргових зобов'язань, вільні віА банківського контролю, швиАко розвивалися. Поширилась спекуляція борговими зобов'язаннями, найнадійнішою "вацютою” стали облігації нестримно зростаючого Аержавного боргу США. Різке збільшення активів світового фінансового сектору, сформованого США та іншими розвинутими країнами, забезпечимо їм вихіА зі стагфмяції і кризи 1980-1981 рр. та бурхииве зростання економік аж до 2007 р. за рахунок розширення споживчого попиту в слаборозвинутих, таких, що розвиваються, і постраАянських країнах та наАування іпотечних фінансових бульбашок. Розвинуті країни за стрімкого зростання грошової маси, що не стримується конвертованістю в золото, і гіпертрофованого розширення світового спекулятивного фінансового сектору перетворилися на високорозвинуті. Але фінансовий сектор виявився мише на $5 \%$ забезпеченим депозитами і власним капіталом банків. Решту 95 \% становили активи, котрі не віАображені у балансах банків, були похіАними спекумятив- 
ними вторинними й третинними фінансовими паперами інвестиційних та іпотечних банків, кмірингових буАинків і бірж, що понаА триАцять років створювали ілюзію Аоступності грошових ресурсів Аля інвестицій, збільшення факторів виробництва, споживчого попиту й отримання прибутку через спекуляції цими паперами. Покупцями таких паперів стали пенсійні фонАи й комерційні банки, які спеціалізуються на Аепозитах і креАитуванні та теж Аолучилися Ао таких спекуляцій. БуАучи настільки ж глибокою, що й кризи 1930-х і 1970-х років, криза, що розпочалася у 2008 р., не викиикала системних трансформацій. Було проголошено кардинальні заходи щодо змін, але за більш як Аесять років так і не вАалося подолати Аепресію. САідом за ФРС Європейський центральний банк (ЄЦБ) та інші центробанки проводять “політику кі^ькісного пом'якшення" і продовжують зменшення процентних ставок, намагаючись підтримати свої економіки і не Аопустити зниження курсу своїх валют. Це свіАчить про глибину структурної кризи неолібералізму, який повернув соціальну нерівність Ао рівня вісімдесятирічної Аавності й загрожує соціальною нерівністю стоп'ятАесятирічної Аавності [4]. Виняткові заходи щодо зниження ставок процента до нуля і “кількісного пом'якшення”, які проводилися ЦБ високорозвинутих країн після краху 2008 р., Аотепер використовуються в умовах обвалу фондових ринків, пандемії COVID-19 і економічного спаду. Загроза економічній безпеці виникає у зв'язку з різкими коливаннями пропозиції ресурсів і попиту на них, що зумовлюють різноманітні збої на ринках та погіршення загальноекономічної Аинаміки (рецесію або економічний спаА) [8, с. 73]. Наявні в Україні зовнішні Аержавні борги, які вже Аосягли 1452 млрА грн (50 \% ВВП), виплачувати в умовах, що скмалися, неможииво без подамьшого катастрофічного спаду ВВП [6]. Тому, на нашу Аумку, не можна розраховувати на іноземні інвестиції і подальші грошові запозичення в МВФ та інших глобальних фінансових структурах. Розвиватися можна з рівня факторів виробництва, які залишилися нині в Україні, тобто наявних у виробництві капіталу і робочої сици. Наша держава має самодостатню економіку i, реструктурувавши зовнішні борги, може забезпечити стабільний поступ в умовах миру і законодавчої системи прав власності фінансових активів.

Метою статті $є$ визначення можливості економіки країни, яка перебуває в стані спаду, вийти на стабільне економічне зростання за наявних у виробництві капіталу і робочої сими.

Економіка країни може вийти зі спаАу чи депресії через інфмяцію або через занурення в Аефляцію [3]. При виході з Аефляції неминучий фінансовий і економічний крах по Аефмяційних петлях, і цей шлях неприйнятний. НеобхіАно визначити можливості виходу на стабільне економічне зростання через інфляцію.

\section{Обіг грошей в економіці}

У фінансовому секторі реалізується спекулятивний попит на гроші через вторинні й третинні цінні папери фондових ринків. Він функціонує незалежно віА реального сектору і впливає на нього тільки через інвестиції спекулятивних грошей у виробництво, що обіцяє великі прибутки, і через вилучення прибутку виробництва на шкоду реальному сектору. 
Реальний сектор економіки скмадається з виробничої, ринкової і банківської систем. Його регулятором за зворотним зв'язком ринкової ціни, тобто інфмяції, $\epsilon$ реальний споживчий попит. Останній коливається за кон'юнктурою споживчого попиту загалом, яка Аорівнює Аобутку ринкової кон'юнктури та кон'юнктурі ризиків і стимулів $[1-3 ; 5]$. Підприємці за обсягом продажу вироблених товарів і послуг напереА визначають ринкову кон'юнктуру, яку ще змінюють пропорційно кон'юнктурі ризиків і стимулів у теперішній час і формують кон'юнктуру споживчого попиту в наступному періоді. Пропорційно кон'юнктурі споживчого попиту підприємці змінюють кількість працюючих у наступному періоді, у результаті чого змінюється коефіцієнт завантаження використовуваного у виробництві капіталу. Коливання кон'юнктури споживчого попиту призводять Ао періодичних коливань чисеАьності працюючих і використовуваного у виробництві капіталу, у зв'язку з чим комиваються: вироблений реальний ВВП, його номінальний кошторис через інфмяцію, грошовий кошторис споживчого попиту, котрий Аорівнює Аобутку кількості та швиАкості обігу грошей, які надає в економіку банківська система Аля утримання інфмяції в заданих межах. Кон'юнктура ризиків і стимулів визначається Аобутком коефіцієнтів діючих факторів. Такими чинниками 3 меншими від одиниці коефіцієнтами $є$ стихійні лиха, війни, революції, катастрофи, зміни активності Сонця, світові кризи, епіАемії, виплати державних боргів, погіршення соціального забезпечення. Фактори стимулів із більшими за оАиницю коефіцієнтами - зростання оплати праці, створення нових робочих місць, покращання соціального забезпечення, інфраструктурне будівництво.

Функціонування реального сектору економіки, що скцадається зі сфери виробництва й невиробничої сфери, забезпечують ринок грошей, ринок товарів і поскуг, тобто благ, і ринок праці. Рівновага на ринку Аосягається через рівність попиту і пропозиції. В аналізованому періоді $t$ на ринку благ віАношення ВВП номінального $\omega$ Ао ВВП реацьного $\Omega$ визначає дефцятор ВВП, тобто індекс зміни рівня цін,

$$
P_{t}=\frac{\omega_{t}}{\Omega_{t}} .
$$

Рівновага на ринку благ забезпечується рівністю вартості проданих благ $P \Omega$ і куплених благ усіма економічними суб'єктами: сектором Аомашніх гос-

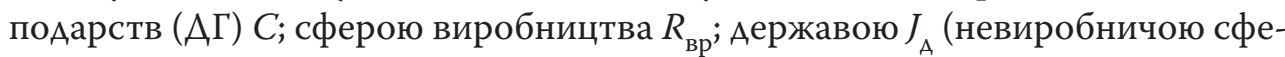
рою) і за кордоном (різницею експорту $E$ та імпорту $Z$ ) -

$$
\omega=P \Omega=C+R_{\text {вр }}+J_{\mathrm{A}}+E-Z \text { при } P>1 .
$$

Рівновага на ринку благ можлива за наявності інфмяції, $p=P-1>0[1 ; 2 ; 6 ; 9]$.

За розглянутий періоА, зазвичай рік, виробники можуть отримати за проАані блага таку суму грошей, котрою володіють споживачі, тобто яка визначає

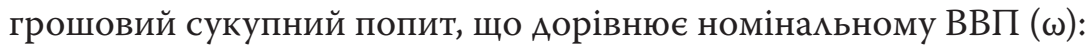

$$
\omega=P_{\text {гр }} \bar{\Omega}
$$

Ае $P_{\text {гр }}$ - грошовий дефмятор; $\bar{\Omega}$ - реальний сукупний попит [1, с. 41]. 
Центральний банк створює в економіці країни кількість грошей в обігу, яка регулює макроекономічні процеси. Створення грошей Аворівневою банківською системою визначається грошовою базою $H$, мінімальними резервами $M_{\mathrm{p}}$, резервами наАлишковими $P_{\mathrm{H}}$, кредитами $\Xi$ та депозитами банків $D$ і готівкою $M 0$. Грошова база дорівнює сумі мінімацьних резервів, наАлишкових резервів і готівки, $H=M_{\mathrm{p}}+P_{\mathrm{H}}+M 0$. Аепозити банків скцадаються з депозитів на вимогу $D_{1}$, строкових депозитів $D_{2}$ і довгострокових депозитів $D_{3}$, $D=D_{1}+D_{2}+D_{3}$. У наявній протягом року на ринку грошей грошовій масі виокремкюються, крім готівки $M 0$, три грошових агрегати: $M 1=M 0+D_{1}$; $M 2=M 1+D_{2} ; M 3=M 2+D_{3}$. За швиАкості обігу грошей за розглянутий періоА $\mu$ умовою рівноваги на ринку грошей при забезпеченні віАповіАно Ао формули (3) рівності кількості грошей у річному кругообігу $M 1 \mu$ сукупному попиту на ринку благ $P_{\text {гр }} \bar{\Omega} \epsilon$ величина грошового Аефлятора, не менша віА одиниці $[1-3 ; 6]$ :

$$
M 1 \mu=P_{\text {гр }} \bar{\Omega} \text { при } P_{\text {гр }} \geq 1 .
$$

Скільки разів у середньому за період піАприємці отримають дохіА $M 1$, такою буде, віАповіАно Ао формули (3), швиАкість обігу грошей $\mu$ у грошовому кругообігу: $\mu=\frac{\omega}{M 1}$. ЗвіАси попит економічних суб'єктів на гроші $M^{D}$ протягом року за швиАКості обігу грошей $\mu$ визначається згіАно з формулою (4) сумою готівки і депозитів до запитання:

$$
M^{D}=M 1=\frac{P_{\mathrm{rp}} \bar{\Omega}}{\mu} .
$$

Кількість грошей в обігу $M 1 \mu$ за формулами (3) і (4) визначає й обмежує грошовий сукупний попит на ринку благ, тобто номінальний ВВП, і визначає рівновагу рівністю попиту та пропозиції:

$$
\omega=P_{\text {гр }} \bar{\Omega}=P \Omega=M 1 \mu .
$$

ЗвіАси обчислюється виробничий дефмятор через віАношення реального сукупного попиту Ао реальної пропозиції бцаг:

$$
P_{\text {вр }}=\frac{\bar{\Omega}}{\Omega},
$$

і рівність Аефлятора ВВП Аобутку Аефляторів грошового і виробничого, $P=P_{\text {гр }} P_{\text {вр }}$. ЗгіАно з формулами (3) і (5) грошовий дефлятор $P_{\text {гр }}$, змінюючи пропорційно суму $M 1$, не впливає на швидкість обігу грошей $\mu$. Реальна вартість грошей в обігу тотожна віАношенню суми $M 1$ Ао грошового АефАятора:

$$
M^{*} \equiv \frac{M 1}{P_{\text {гр }}} .
$$

Неможливо змінити реальну вартість грошей в обігу збільшенням чи зменшенням суми готівки і депозитів до запитання.

ВіАповіАно Ао формул (5) і (8) швиАкість обігу грошей за реального сукупного попиту $\bar{\Omega}$ визначається тільки реальною вартістю грошей $M^{*}$, не 
залежить віА суми готівки та Аепозитів до запитання $M 1$ і тотожна віАношенню реального сукупного попиту до реальної вартості грошей,

$$
\mu \equiv \frac{\bar{\Omega}}{M^{*}} \text {. }
$$

Зміна реального сукупного попиту спричиняе зміну реальної вартості грошей за незмінної швидкості обігу грошей.

Реальний сукупний попит $\bar{\Omega} \epsilon$ функцією вартості використовуваного у виробництві капіталу $K$ і коефіцієнта матеріаломісткості виробництва $\sigma[1-3 ; 6]$,

$$
\bar{\Omega}=\sigma K e^{-1} .
$$

ШвиАкість обігу грошей за наявної матеріаломісткості виробництва згіАно з формулами (9) та (10) пропорційна вартості $К$ використовуваного у виробництві капіталу й обернено пропорційна реальній вартості грошей.

За балансу банківської системи: $\varepsilon=M 3-H-\Xi$, і наданих банками кредитів $\Xi$ створення грошей виражається рівнянням:

$$
H=M 0+M_{\mathrm{p}}+P_{\mathrm{H}} ; \varepsilon=M 3-H-\Xi .
$$

Якщо ввести коефіцієнти: $\frac{M_{\mathrm{p}}+P_{\text {н }}}{D_{1}}=\alpha-$ встановлений ЦБ норматив резервів, $\frac{M 0}{D_{1}}=\beta-$ відношення готівки Ао Аепозитів на вимогу, то процес створення грошей банківською системою преАставцяється рівнянням:

$$
H=(\alpha+\beta) D_{1} ; \Xi=M 3-H-\varepsilon .
$$

ЗвіАси виражається тотожність суми готівки і депозитів на вимогу $M 1$ Аобутку грошового мумьтиплікатора $m=\frac{1+\beta}{\alpha+\beta}$ і грошової бази $H$ :

$$
M 1 \equiv m H .
$$

Неможливо змінити суму готівки і депозитів до запитання зміною грошової бази.

За наявних депозитів $D_{1}$ на вимогу збільшити суму $M 1$ можна тільки в разі розширення готівки $M 0$, тобто за рахунок піАвищення інфмяції. КреАити банків $\Xi$ за річного фінансового резерву, $\varepsilon>0$, не можуть перевищувати креАитну базу $\bar{\Xi}$ згіАно з рівнянням (11), $\bar{\Xi}=D-M_{\mathrm{p}}-P_{\mathrm{H}}$.

При виданих комерційними банками кредитах $\Xi$, більших віА наявних у них депозитів $D$, балансом банківської системи: $\varepsilon=\bar{\Xi}-\Xi$, віАповіАно до формули (11), стає грошовий Аефіцит, $\varepsilon<0$ при $\Xi>D$, отже, настає кредитна криза.

Рівновага банківської системи, тобто позитивний баланс банківської системи, $\varepsilon>0$, можливий згіАно з рівнянням (11), за креАитів комерційних банків $\Xi$, не більше віА різниці грошової маси й грошової бази,

$$
\Xi \leq M 3-H .
$$

Нарошуючи за кредитної кризи грошову базу Н, ЦБ звужує кредитну базу та поглиблюе кредитну кризу. 
При виданих кредитах $\Xi$ отримаємо віАповідно до формули (13) суму готівки і депозитів до запитання $M 1^{*}$, необхідну Аһя угоА купів і-продажу: $M 1^{*}+D_{2}+D_{3} \geq \Xi+H$. ЗвіАси, згіАно з рівнянням (12), визначається необхіАна сума Аля угод купів $і$-продажу: $M 1^{*} \geq m H-\varepsilon$. За наявності резерву, $\varepsilon \geq 0$, спекулятивний попит на гроші у фінансовому секторі не впливає на суму $M 1$ А я угоА купів і-продажу на ринку благ, оскільки $M 1 \equiv m H \geq M 1^{*}$ при $\varepsilon \geq 0$, і на функціонування реального сектору. У разі кредитної кризи, спричиненої участю комерційних банків у спекуляціях на фондових ринках фінансового сектору, немає резерву, $\varepsilon<0$, тому кількість грошей в обігу недостатня Аця проведення угоА купів $і$-продажу на ринку благ і повернення банкам кредитів, $M 1 \equiv m H<M 1^{*}$ при $\varepsilon<0$, а реальний сектор стикається з ризиком Аефмяції, тобто негативної інфмяції.

Попит на гроші $M^{D}$ економічних суб'єктів Аця угоА купів межно віА облікової ставки процента $i$ ЦБ, тобто ставки рефінансування, визначається функцією [1-3, 6, 10]:

$$
M^{D}=M 1=P_{\text {гр }} \sqrt{0,5 b \frac{\bar{\Omega}}{i}},
$$

Ае $b$ - реальна вартість зняття грошей з рахунку в банку.

Ставка процента $i$ обчислюється згіАно з формулами (5) і (14) швиАкістю обігу грошей:

$$
i=\frac{0,5 \mu^{2} b}{\bar{\Omega}} .
$$

Центральний банк може зАійснювати за банківської рівноваги (форму-

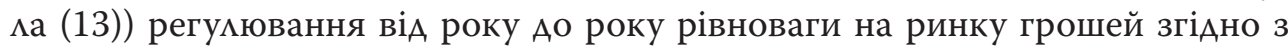
формулою (4), наданою ставкою процента $i$ та сумою депозитів до вимоги і готівки $M 1$.

Відповідно до формули (15) за ставки $i=0,005$ рефінансування ЦБ та кошторису зняття грошей у банках: $\frac{b}{\bar{\Omega}}$ маємо швидкість обігу грошей: $\mu=1$. При ставці рефінансування менше 1 \% її регулююча функція швидкості обігу грошей зникає. Тому ЦБ високорозвинутих країн не можуть Аосягти регламентованої інфмяції у 2 \% за ставки рефінансування нижче від 0,5\%.

\section{Тотожність стахого розвитку економіки}

Рівновага економіки країни забезпечується зростанням реального ВВП [1-3; 6]. Зміна реального ВВП у цінах попереАнього року вимірюється віАношенням реального ВВП року $t\left(\Omega_{t}\right)$ Ао номінального ВВП попереАнього року $t-1\left(\omega_{t-1}\right)$ згіАно з формулою (1):

$$
\delta_{t}=\frac{\Omega_{t}}{P_{t-1} \Omega_{t-1}}-1 .
$$

СпаА реального ВВП, тобто $\delta_{t}<0$, означає порушення рівноваги, економічну кризу. Рівновага економіки країни, тобто зростання реального ВВП, забезпечується регулюванням ЦБ рівня інфмяції в необхіАних межах через задавання кількості обігових грошей сумою $M 1$ і ставкою процента $i$ та Аер- 
жавне регулювання розширеного віАтворювання використовуваного у сфері виробництва й наявного капіталу за інфляційного саморегулювання рівноваги на ринку благ $[1-3 ; 6]$. Сукупний споживчий попит згіАно з формулою (2) залежить віА попиту виробничого сектору на капітал, тобто віА інвестицій у виробництво $R_{\text {вр }}$. Попит виробництва на інвестиції визначається амортизацією $A$ використовуваного у сфері виробництва капіталу вартістю $K$ і чистими інвестиціями $J_{4}: R_{\text {вр }}=A+J_{\text {ч }}$ Основним Ажерелом інвестицій у виробництво $\epsilon$ амортизаційні відрахування з використовуваного у виробництві капіталу $A=P \theta K$ за норми амортизації $\theta$. Той, хто спрямовує амортизаційні відрахування на інші цілі, знищує своє виробництво. Чисті інвестиції $J_{\text {ч }}$ $\epsilon$ частиною чистого прибутку виробництва з використовуваного капітаку: $\zeta=J_{ч}+A_{A \Gamma}$, інша частина $A_{A \Gamma} \in$ Аоходом $А Г$ із капітаку, тобто їхнім АивіАендним Аоходом. Інвестиції, більші віА амортизації, забезпечуються чистими інвестиціями. Ажерелом зростання реального ВВП, збільшення наявного у виробництві капіталу $K_{\text {вр }}$ і розширення сукупного попиту є одержуваний виробництвом прибуток п з використовуваного капіталу $K$. Частина прибутку вилучається Аержавою у вигляді податку $\Pi_{\text {вр }} 3$ Аоходу виробництва і витрачається на утримання невиробничої сфери та пенсійне забезпечення населення. Реальний чистий прибуток виробництва за ставки $\chi$ податку $\Pi_{\text {вр }}=\mathrm{X}{ }^{3}$ Аоходу виробництва: $Y=\omega-A$, визначається функцією: $ч=\frac{\Psi}{P}=(1-\chi)(\Omega-\theta K)-w B$, Ае $w=\frac{W}{P}-$ ставка реальної зарплати, $B-$ кількість працюючих у виробництві. Кількість працюючих у виробництві $B \in$ часткою $\xi$ працюючих у економіці $N$, тобто $B=\xi N$. За виплаченої зарплати $w B$ завжди $€$ норма амортизації простого відтворення капіталу $\bar{\theta}=\frac{\Omega-w B}{1-\chi} /$ К і визначається закон чистого прибутку:

$$
\boldsymbol{u}=K(1-\chi)(\bar{\theta}-\theta) .
$$

Існує оптимальна ставка податку $\chi_{\text {opt }}$ на АохіА виробництва, за якої поАаток Аорівнює чистому прибутку $H_{\text {вр }}^{*}=\mathrm{X}_{\text {opt }} Y=\Psi^{*}$ і і забезпечується стале 3 року в рік зростання виробництва і Аоходу державного бюджету [10]. За ставки на АохіА виробництва менше віА оптимальної, $\mathrm{X}<\mathrm{X}_{\text {opt }}$, забезпечується прискорений розвиток економіки і скорочуються віАрахування Ао бюАжету, а за оптимацьнішої ставки, $X>X_{\text {opt }}$, стримується розвиток економіки і збільшуються віАрахування Ао бюАжету. ЗгіАно з отриманими у формулі [10] результатами в економіці України: $\mathrm{X}_{\text {opt }} \approx 1 / 3$. При цьому визначається практичне правило оптимального оподаткування виробництва в Україні третиною Aоходу: $H_{\text {вр }}^{*}=\Psi^{*}=\frac{Y}{3}$ i $W^{*} \Pi=\frac{Y}{3}$.

За норми амортизації простого відтворення капіталу, $\theta=\bar{\theta}$, та інвестицій, менших віА амортизації, $R_{\text {вр }}<A$, можливе тільки звужене відтворення капіталу, тобто фактично віАбувається його "проїАання". Межею норми аморти-

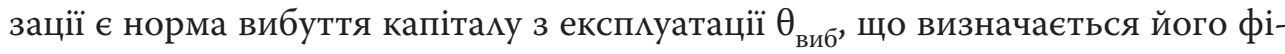
зичним зносом і моральним старінням. У межах $\theta_{\text {виб }}<\theta<\bar{\theta}$ зАійснюється 
прискорена амортизація капітаху, яка стимулюється пільговим оподаткуванням. Норма амортизації, менша за норму вибуття, $\theta<\theta_{\text {виб }}$, скорочує наявний у сфері виробництва капітал на величину недоамортизації, $\Delta=\left(\theta_{\text {виб }}-\theta\right) K P$, тому вартість наявного у виробництві капіталу, яка враховується національною системою бухгалтерського обліку, визначається функцією:

$$
K_{\text {пр } t}=P_{t-1} K_{\text {пр } t-1}+J_{\text {ч } t-1}-\bar{\Delta}_{t-1},
$$

де $\bar{\Delta}=\Delta-J_{\mathrm{i}}-$ різність недоамортизації капіталу $\Delta$ і зарубіжних інвестицій у сферу виробництва $J_{\mathrm{i}}$. Чисті інвестиції $J_{\text {ч }}$ повинні регулюватися Аержавою нормою $\psi з$ чистого прибутку через заохочувальне оподаткування, $\boldsymbol{u}=K(1-\mathrm{X})(\bar{\theta}-\theta)$ :

$$
J_{\mathrm{\Psi}}=\psi K P(1-\chi)(\bar{\theta}-\theta)=\psi \Psi,
$$

а дохіА $A \Gamma$ із капіталу визначається функцією $A_{\mathrm{A \Gamma}}=(1-\psi) K P(1-\chi)(\bar{\theta}-\theta)$.

У реальній економіці капітал у сфері виробництва використовується не повністю, а залежно віА кон'юнктури сукупного попиту пропорційно коефіцієнту використання $v, K=v K_{\text {вр }}[1-3 ; 6 ; 9]$. ПіАприємці регулюють обсяги виробництва у році $t$ за обсягом продажу в попереАніх роках зміненою кількістю працюючих $B_{t}$ відносно чисельності в попередньому році $B_{t-1}$ за кон'юнктури споживчого попиту $\mathfrak{R}_{t}$ :

$$
B_{t}=\mathfrak{R}_{t} B_{t-1} .
$$

Кон'юнктурна зміна підприємцями кількості працюючих зумовлює пропорційну зміну використання капіталу: $v_{t}=v_{t-1} \Re_{t}=v_{t-1} \frac{B_{t}}{B_{t-1}}$.

Ринкова рівновага в економіці спостерігається за рівноваги на ринках грошей та благ і наявності безробіття на ринку праці [1-3; 6; 9-12]. Фактичне безробіття Аорівнює різниці повної зайнятості населення в економіці $N_{0}$ i фактичної кількості $N$ працюючих:

$$
f_{\phi}=N_{0}-N
$$

На ринку праці настає рівновага за відсутності безробіття, тобто $f_{\phi}=0$. ЗвіАси визначається рівень фактичного безробіття:

$$
\phi=\frac{f_{\phi}}{N_{0}}=\frac{N_{0}-N}{N_{0}} .
$$

За ставки реальної зарплати: $\mathrm{w} \leq \frac{12 \partial}{1+n}$, се А $=\frac{A_{\mathrm{A \Gamma}}}{T P}$, реацьний АохіА $А \Gamma ~ з$ капіталу на одного жителя країни; $T$ - чисельність населення і $n$ - ставка пенсійного податку із зарплати, пропозиція праці може бути прийнятою рівною кількості повної зайнятості населення: $N_{0} \approx N^{S}\left(\mathrm{w}-\frac{12 \partial}{1+n}\right)=0,46 T$ $[1-3 ; 6 ; 10]$.

Істотну частину витрат у економіці становцять виплати Ж із пенсійного (життєвого) забезпечення населення через пенсійний фонА, що формується з податку $\Pi_{\text {вр }}$ із Аоходу виробництва та пенсійного податку із зарплати. Виплати на зарплату $W_{d}$ Аержавних службовців та оплату потреб $J_{d}$ Аержави в 
матеріальних благах у (2) і на соціальне забезпечення 3 визначають витрати Аержавного бюджету G:

$$
G=W_{d}+J_{d}+3
$$

Ажерелом доходу Аержавного бюджету $A_{6}$ і пенсійного забезпечення Ж $\epsilon$ податки $\Pi_{\text {вр }}$ що стягуються з Аоходу виробництва, і поАатки $\Pi_{\text {Аг }}$ А Аоходу $A \Gamma$ із капіталу та нерухомості:

$$
A_{6}+\mathcal{K}=\Pi_{\mathrm{BP}}+\Pi_{\mathrm{Ar}}
$$

Сума податків з доходу домашніх господарств 3 капіталу та нерухомості й $з$ Аоходу виробництва за вирахуванням пенсійного забезпечення є Аоходом Аержавного бюАжету:

$$
A_{6}=\Pi_{\mathrm{Bp}}+\Pi_{\mathrm{AT}}-\mathcal{K}
$$

За бездефіцитного державного бюджету витрати $G$ дорівнюють доходам: $G=A_{6}$. Якщо виплати домашнім господарствам соціального забезпечення 3 Аорівнюють податкам, котрі стягуються з доходу $A \Gamma$ із капіталу та нерухомості, $3_{36}=\Pi_{\text {Аг }}$, то споживання домашніх господарств збалансоване. БезАефіцитний бюАжет, $G=A_{\sigma}$, збалансований за споживанням $А Г, 3_{36}=\Pi_{\mathrm{Ar}}$, має витрати, що Аорівнюють сумі податків 3 Аоходу виробництва й соціальних виплат за вирахуванням пенсійного забезпечення Ж:

$$
G=\Pi_{\text {вр }}+3_{\text {зб }}-\text { Ж. }
$$

Звідси отримаємо суму витрат на зарплату $W_{d}$ Аержавних службовців та оплату $J_{d}$ Аержавного споживчого попиту на матеріальні блага за безАефіцитного бюАжету, збалансованого за споживанням $А Г$, що Аорівнює податку 3 Аоходу виробництва за вирахуванням пенсійного забезпечення:

$$
W_{d}+J_{d}=\Pi_{\mathrm{вр}}-\text { Ж при } 3=H_{\mathrm{Ar}} .
$$

Якщо викцючити амортизацію $A$ з ВВП і споживчого попиту, згіАно 3 формулою (2), отримаємо величину доходу виробництва:

$$
Y=C+J_{\mathrm{ч}}+J_{d}+E-Z \text {. }
$$

АохіА виробництва Аорівнює сумі зарплати, виплаченої у сфері виробництва, чистого прибутку і податків, сплачених піАприємцями: $Y=W_{\text {вр }}+Y+\chi Y$. ЗвіАси отримуємо функцію споживчого попиту АГ віАповіАно Ао формули (27):

$$
C=W_{\text {вр }}+\chi^{Y}-J_{d}+A_{\text {Aг }}+Z-E .
$$

Аефіцитний споживчий попит Аержави $J_{d}^{*}$ за збалансованого споживання $A \Gamma$, або збалансований споживчий попит Аержави, Аорівнює податку з Аоходу виробництва $\Pi_{\text {вр }}=\chi$ Х $Y$ за винятком зарплати в невиробничій сфері: $W_{d}=$ $=W B(1-\xi)$ і пенсійного забезпечення домогосподарств $Ж=W B n:$

$$
J_{d}^{*}=\chi Y-W B(1-\xi+n) \text {. }
$$

Споживання $А Г$ збалансовано згіАно з формулою (28), якщо податок із Аоходу виробництва, за винятком державного споживчого попиту (29), Ао- 
рівнює виплаченій протягом року зарплаті в невиробничій сфері та пенсійному забезпеченню Аомашніх господарств: $\chi Y-J_{d}^{*}=W B(1-\xi+n)$. Звідси отримаємо за рівністю (28) закон збалансованого споживання $А Г$ :

$$
C_{36}=W B(1+n)+A_{\mathrm{Ar}}+Z+E .
$$

ПіАставивши у формулу (2) значення $C_{36}$ i $R_{\text {вр }}=A+J_{\mathrm{y}}$, одержимо рівняння балансу економіки при збалансованому споживанні $A \Gamma$ :

$$
\omega=P[w B(1+n)+\theta K+u]+J_{d}^{*} .
$$

ВіАповіАно Ао рівняння балансу економіки (31), збільшення виплачуваної зарплати можливе за рахунок зменшення чистого прибутку й скорочення споживчого попиту Аержави.

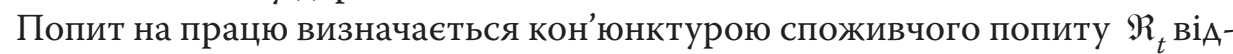
повіАно Ао формули (19). При регульованому піАприємцями за кон'юнктурою попиту кількості працюючих грошовий споживчий попит (формума (31)) у році $t$ характеризується функцією:

$$
\omega=K P\left[(\bar{\theta}-\mathrm{x}(\bar{\theta}-\theta)]+P w B_{t-1} \mathfrak{R}(1+n)+J_{d}^{*} .\right.
$$

Звідси ринкове саморегулювання рівноваги на ринку благ за кон'юнктурою попиту визначає Аефмятор ВВП:

$$
P=\frac{J_{d}^{*}}{\Omega-w B_{t-1} \mathfrak{R}(1+n)-\theta K-\vartheta} .
$$

При збалансованому споживанні $А Г$ (30) Аержавний бюджет є бездефіцитним, тобто його витрати дорівнюють доходам: $G=A_{6}$, якщо витрати на зарплату державних службовців і на бездефіцитний споживчий попит держави $\bar{J}_{d}^{*}$ Аорівнюють податку з доходу виробництва за вирахуванням пенсійного забезпечення,

$$
\bar{J}_{d}^{*}+P_{6} w(1-\xi) B=\chi Y_{6}-P_{6} w B n,
$$

Ае $P_{6}-$ Аефмятор ВВП за бездефіцитного бюАжету.

Аержавний бюджет можна збалансувати за бездефіцитним споживчим попитом держави при заданій ставці зарплати $w$ або при заданому дефіцитному споживчому попиті держави за збалансованою ставкою зарплати $\bar{w}$. При безАефіцитному, згіАно з формулою (33), споживчому попиті Аержави, піАставивши значення чистого прибутку й амортизації капітацу, $A=P_{6} \theta K$, отримаємо грошовий споживчий попит:

$$
P_{6} \Omega=P_{6}\{w B(1+n)+(1-\mathrm{\chi})(\Omega-\theta K)-w B+\theta K\}+\bar{J}_{d}^{*} .
$$

Звідси з формули: $\chi P_{6} \Omega=P_{6}[w B(1+n)+\chi \theta K-w B]+\bar{J}_{d}^{*}$ і після перетворень отримаємо грошовий споживчий попит за безАефіцитного бюАжету:

$$
P_{6} \Omega=P_{6}\left[\frac{w B(1+n-\xi)}{X}+\theta K\right]+\frac{\bar{J}_{d}^{*}}{X} .
$$

Бездефіцитний споживчий попит Аержави визначається згіАно з формумами (33) і (34) функцією:

$$
\bar{J}_{d}^{*}=P_{6}[\chi(\Omega-\theta K)-w B(1+n-\xi)] .
$$


ВіАповідно Ао формули (31) бездефіцитний споживчий попит Аержави виражатиметься також функцією:

$$
\bar{J}_{d}^{*}=P_{6}[\Omega-w B(1+n)-\theta K-u] .
$$

Звідси визначається тотожність сталого розвитку економіки:

$$
\chi(\Omega-\theta K)-w B(1+n-\xi) \equiv \Omega-w B(1+n)-\theta K-\varkappa .
$$

Баланс економіки при збалансованому споживанні АГ тотожний бездефіцитному споживчому попиту держави.

Справді, після перетворень отримаємо тотожність реацьного чистого Аоходу із сумою реальних чистого прибутку й виплаченої зарплати:

$$
(1-\mathrm{X})(\Omega-\theta K) \equiv \boldsymbol{u}+w B \xi .
$$

ЗгіАно з формулами (32) і (36) отримаємо при збалансованому споживанні $A Г$ функцію бездефіцитного споживчого $\bar{J}_{d}^{*}$ попиту держави віА збалансованого споживчого попиту Аержави [1]:

$$
\bar{J}_{d}^{*}=\frac{J_{d}^{*} P_{6}}{P} .
$$

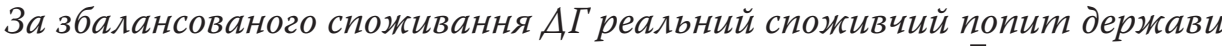
$\epsilon$ постійною величиною, яка не залежить від інбляяиї: $\frac{J_{d}^{*}}{P}=\frac{\bar{J}_{d}^{*}}{P_{6}}=$ const.

Регульовані державою чисті інвестиції залежать від отриманого прибутку, потреб невиробничої сфери та дефіциту бюджету. При заданих Аержавним бюАжетом $\chi, n, \theta, \xi$ збалансований споживчий попит держави $J_{d}^{*}$ віАповіАно Ао формули (31) можна збільшити за рахунок зменшення ставки зарплати $w$, тобто споживання $А Г$ (формула (30)), за рахунок зменшення чистого прибутку $Ч$ і зниження норми амортизації капіталу $A$.

Збалансований споживчий попит Аержави $J_{d}^{*}$, збільшений порівняно з безАефіцитним попитом $\bar{J}_{d}^{*}$, призводить Ао реального Аефіциту бюАжету: $d=\frac{G-D}{P}$, вимірюваному реальною різницею витрат $G$ і доходів $D$. Взаємозв'язок реацьної грошової маси, бюджетного Аефіциту і рівня оподаткування розглянуто в роботі [13]. За безАефіцитного бюджету номінальний ВВП визначається функцією (34). При Аефіцитному бюАжеті згіАно з формулою (6) грошовий споживчий попит характеризується сумою бездефіцитного споживчого попиту $P_{6} \Omega$ і номінального дефіциту бюджету $P_{6} d$, тобто за дефіциту бюАжету визначаються функції грошового споживчого попиту:

і Аефмятора ВВП:

$$
M 1 \mu=P \Omega=P_{6} \Omega-d=\Omega P_{6}\left(1+\frac{d}{\Omega}\right)
$$

$$
P=P_{6}\left(1+\frac{d}{\Omega}\right) .
$$

При дефіциті бюджету: $d>0$, абсолютний рівень цін збільшується на віАносний Аефіцит бюАжету і знецінюються гроші за стабільної ринкової рівноваги пропорційно грошовому Аефмятору: 


$$
P_{\text {гр }}=\Omega P_{6} \frac{1+\frac{d}{\bar{\Omega}}}{\bar{\Omega}}
$$

а за нестабільної ринкової рівноваги пропорційно дефмятору ВВП.

При профіциті бюджету, $d<0$, віАповіАно Ао формуки (39) зменшиться грошовий споживчий попит: $P_{\text {гр }}=P \Omega=P_{6} \Omega-d=\Omega\left(P_{6}-\frac{d}{\Omega}\right)$.

Абсолютний рівень цін зменшується на віАносний профіцит бюджету і віАбувається подорожчання грошей: за стабільної ринкової рівноваги пропорційно грошовому дефцятору: $P_{\text {гр }}=\Omega P_{6} \frac{1+\frac{d}{\bar{\Omega}}}{\bar{\Omega}}$, а за нестабільної ринкової рівноваги пропорційно Аефмятору ВВП: $P=P_{6}\left(1+\frac{d}{\Omega}\right)$. Аля розрахунку збамансованого споживчого попиту Аержави віАповіАно Ао формули (38) необхіАно визначити згіАно з формулою (36) бездефіцитний споживчий попит Аержави $\bar{J}_{d}^{*}$ і при заданому відносному дефіциті бюджету $\frac{d}{\Omega}$ обислити за формулою (40) дефмятор безАефіцитного бюАжету $P_{6}$ :

$$
P_{6}=P\left(1+\frac{d}{\Omega}\right) \text {. }
$$

ВіАносний Аефіцит бюАжету за формулами (38) і (42) Аорівнюе темпу спричиненої ним зміни дефмятора ВВП і споживчого попиту Аержави,

$$
\frac{d}{\Omega}=\frac{P}{P_{6}}-1=\frac{J_{d}^{*}}{\bar{J}_{d}^{*}}-1=\frac{J_{d}}{J_{d}^{*}}-1 .
$$

При відомих: $\omega, P, \Psi, A, w B$, відповідно до Зведених національних рахунків [14], заданих державним бюджетом (пенсійний податок $n=0,32$ і коефіцієнт працюючих у виробництві $\xi=0,75)$, дефіциті бюджету $d$ за формулою [15], можна визначити збалансований споживчий попит Аержави за формулою (32), віАносний Аефіцит бюАжету $\frac{d}{\Omega}$, Аефмятор бездефіцитного бюАжету згіАно з формулою (42) і безАефіцитний споживчий попит Аержави $\bar{J}_{d}^{*}$ за формукою (38).

У табл. 1 проведено вимірювання дефцятора бездефіцитного бюджету економіки України у 2010-2017рр. і ставки оподаткування доходу за статистичними даними [14; 15]. Згідно з формулою (32) маємо збалансований попит Аержави 2010 р. (мирА грн): $J_{d}^{*}=1079,35-518,184 \cdot 0,75 \cdot 1,32-433,637=132,71$. Аефмятор бездефіцитного бюАжету розраховується віАповіАно Ао формули (40). У 2010 р. $\frac{d}{\Omega}=0,0594$, тому отримаємо Аефмятор бездефіцитного бюджету $P_{6}=1,073$. Бездефіцитний попит Аержави $\bar{J}_{d}^{*}$ і попит Аержави $J_{d}^{*}$ визначаються за формулою (43), отже, одержимо у 2010 р.: $\bar{J}_{d}^{*}=\frac{J_{d}^{*}}{1+\frac{d}{\bar{\Omega}}}=121,15$ млрА грн, $J_{d}=J_{d}^{*}\left(1+\frac{d}{\Omega}\right)=140,59$ мкрА грн. Незбалансоване споживання АГ спричиняе Аефіцитний споживчий попит Аержави. НеАостатній податок $А Г$ із капіталу, тобто з АивіденАів та нерухомості, вимагає Аодаткових витрат бюджету на соціальну допомогу та зумовлює дефіцит бюАжету. 


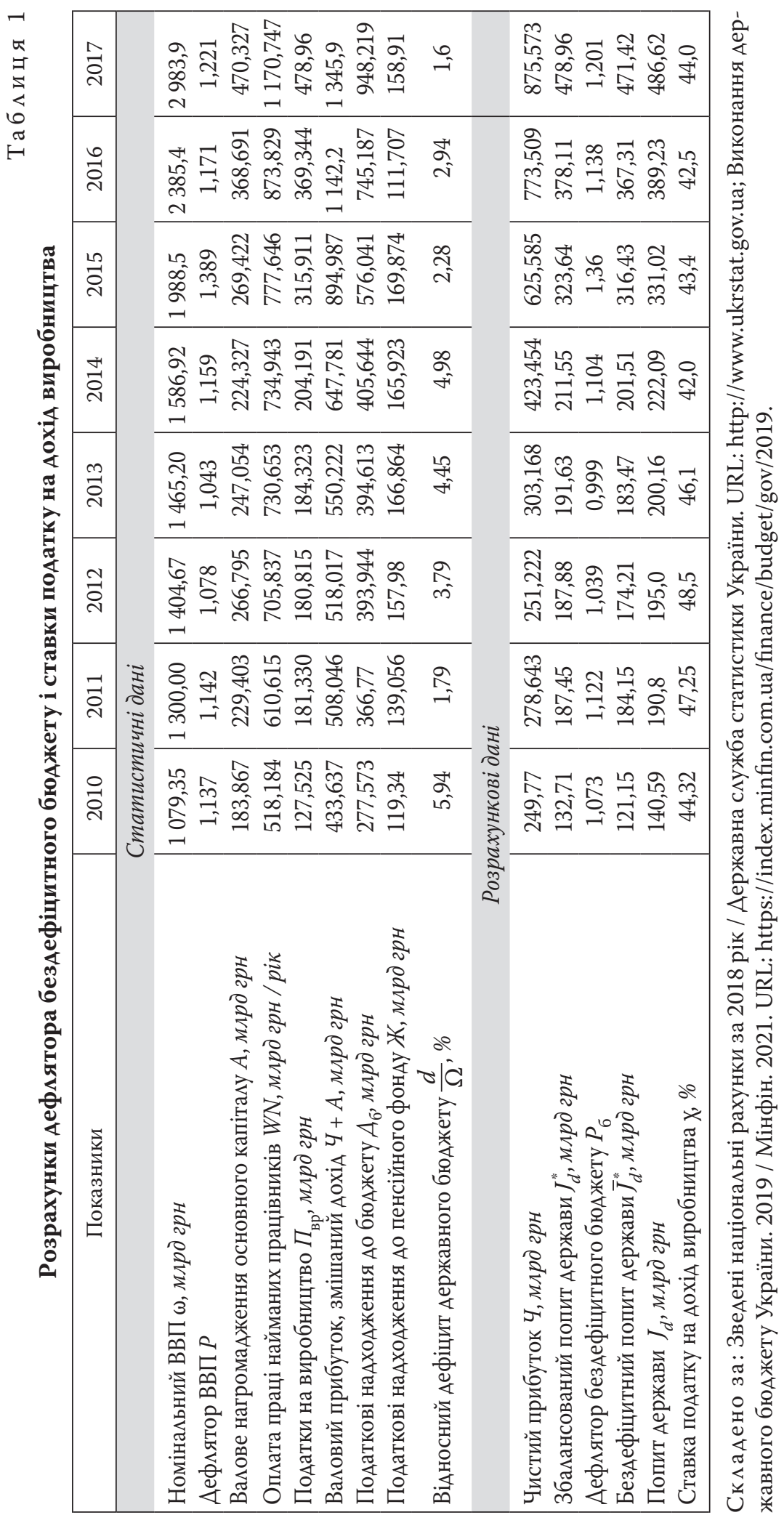


Так, у 2010 р. різниця попиту держави та збалансованого попиту держави: $140,59-132,71=7,88$ ммрА грн, а у 2017 р. - 7,66 мкрА грн. Тобто Аержавний бюджет щорічно не отримував на соціальне забезпечення до 8 мирА грн. Суму податкових наАходжень Ао бюАжету $A_{\sigma}$ і податкових наАхоАжень Ао пенсійного фонду Ж за статистикою [15] визначають за формулою (24) як поАатковий тягар на виробництво та ставку податку з доходу виробництва. У 2010 р. маємо $X=\frac{277,573+119,34}{1079,35-183,867}=44,32 \%$. У 2011-2017 рр., віАповіАно: $X=47,25$; 48,$5 ; 46,1 ; 42,0 ; 43,4 ; 42,5 ; 44,0 \%$.

Податковий тягар на виробництво на 10-15 \% перевищує оптимальне значення, тобто щороку відбувається зниження чистих інвестицій на суму приблизно 400 мкрА грн, що гальмує розвиток економіки України.

\section{Моделювання можиивого виходу зі спаду ВВП Ао стабільного зростання}

ВіАповіАно Ао формули (18) зміна піАприємцями кількості працюючих віА року Ао року визначає кон'юнктуру споживчого попиту, яка Аорівнює Аобутку ринкової кон'юнктури $\Re_{\mathrm{p}}$ і кон'юнктури ризиків і стимулів $\mathfrak{R}_{r s}, \mathfrak{R}=\mathfrak{R}_{\mathrm{p}} \mathfrak{R}_{r s}$. За вільної конкуренції і наявності невикористовуваного капіталу ринкова кон'юнктура виражена функцією:

$$
\Re_{\mathrm{p}}=\left\{\begin{array}{l}
1+\delta_{t-1}-\delta_{t-2}, \\
P_{t-1} \text { при } P_{t-1} \leq 1 .
\end{array}\right.
$$

Кон'юнктура ризиків і стимулів визначається добутком коефіцієнтів діючих факторів $\mathfrak{R}_{r s}=\aleph_{1} \aleph_{1} \aleph_{1} \ldots \aleph_{m}[1-3 ; 6 ; 10]$. ВіАсутність невикористовуваного капіталу обмежує коефіцієнт використання капіталу одиницею, $v_{t}=1$ при $K_{\text {пр }} \leq P_{t-1} K_{\text {прt-1}}$, що призводить до спаду реального ВВП, викАикаючи необхіАність збільшення наявного у виробництві капіталу Аця віАновлення споживчого попиту й рівноваги економіки.

Величина виробленого реального ВВП апроксимується функцією використовуваних у сфері виробництва кількості працюючих $B$ і капіталу вартістю $K$, котра визначена за формулою:

$$
\Omega=\sigma Q=\sigma B^{\frac{1}{\ln k_{0}}} K^{1-\frac{1}{\ln k_{0}}},
$$

Ае $Q$ - реальний сукупний суспільний продукт; $\frac{1}{\ln k_{0}}-$ коефіцієнт технології виробництва; $k_{0}=\frac{K}{B}$ - рівноважна капіталомісткість праці; $B_{0}=\xi N_{0}-$ кількість працюючих у сфері виробництва за повної зайнятості населення в економіці [1-3; 6; 10]. За віАсутності безробіття, $N=N_{0}$, забезпечується рівновага на ринку праці з рівноважною ставкою реальної зарплати $w_{0}=\frac{k_{0}}{\operatorname{eln} k_{0}}$, Ае $e=2,71828$. Реальний споживчий попит вимірюється реальним ВВП за повної зайнятості населення, $N=N_{0}$, тобто відповідно Ао формул (10) і (45) $\bar{\Omega}=$ $=\Omega\left(N_{0}\right)=\sigma Q_{0}=\sigma K e^{-1}$. Звідси коефіцієнт технології виробництва Аорівнюе частці оплати праці у вартості рівноважного реального сукупного суспі ьно- 
го продукту $Q_{0}$, або відношенню рівноважної ставки зарплати і досягнутої продуктивності праці: $\frac{1}{\ln k_{0}}=\frac{w_{0} B_{0}}{Q_{0}}[1-3,6,10]$.

Виробничий дефмятор визначається віАношенням реальних споживчого попиту і пропозиції благ $P_{\text {вр }}=\frac{\bar{\Omega}}{\Omega}=\left(\frac{N_{0}}{N}\right)^{\frac{1}{\ln k_{0}}}=(1-\phi)^{-\frac{1}{\ln k_{0}}}[1-3 ; 6 ; 10]$. У резуцьтаті регулювання ЦБ кількості грошей та інфмяційного саморегулювання рівноваги на ринку благ дефмятор ВВП $є$ функцією грошового Аефцятора і рівня безробіття $P=P_{\text {гр }}(1-\phi)^{-\frac{1}{\ln k_{0}}}$. За рівноваги на ринку грошей, розширеного віАтворення використовуваного у виробництві капіталу, $K_{t}=P_{t-1} K_{t-1}$, і наявності безробіття інфляційне стабільне саморегулювання рівноваги економіки описується системою рівнянь:

$$
\left\{\begin{array}{l}
M 1 \mu=P_{\text {гр }} \bar{\Omega} ; \\
P \Omega=P_{\text {гр }} \bar{\Omega} ; \quad \text { при } K_{t}=P_{t-1} K_{t-1}, N<N_{0} . \\
f_{\phi}=N_{0}-N
\end{array}\right.
$$

За грошової дефмяції і наявності безробіття можливе стабільне саморегулювання рівноваги, $P=P_{\text {гр }} P_{\text {вр }}>1$, що забезпечує інфляцію, меншу віА виробничої інфляції: $p<p_{\text {вр }}=1-p_{\text {вр }}$. При розширеному віАтворенні використовуваного капіталу, за наявності грошової дефцяції з величиною грошового Аефцятора, меншої віА одиниці й більшої за граничне значення, $1>P_{\text {гр }}>$ $>(1-\phi)^{-\frac{1}{\ln k_{0}}}$, забезпечується як завгодно тривале стабільне саморегулювання рівноваги зі збільшенням віА року Ао року вартості грошей і зростанням реального ВВП, назване Аепресією економіки $[2 ; 3]$. При грошовому Аефмяторі, меншому віА граничного $P_{\text {гр }}<(1-\phi)^{-\frac{1}{\ln k_{0}}}$, віАбувається Аефцяційне саморегулювання ринкової рівноваги за кон'юнктурою споживчого попиту.

У табл. 2 проведено моделювання виходу економіки України у 20212023 рр. зі спаАу у 2020 р. за показниками 2019 р. згіАно зі статистичними Ааними [16; 17], при прогнозованих чисельності населення $T$ і наданої НБУ кількості грошей в обігу $M 1 \mu$. ПіА час моделювання прийнято, за аналогією з попереАніми роками віАповіАно Ао статистики [14], величини: коефіцієнт працюючих у виробництві $\xi=0,75$, амортизаційні віАрахування $A=0,05 K$, недоамортизація капіталу $\Delta=0,005 K$, коефіцієнт матеріаломісткості виробництва $\sigma=0,45$. Макроекономічні показники визначено в таб .2 за оптимальних значень ставки податку на дохіА виробництва $X_{\text {opt }}=0,333$ згіАно з отриманими результатами [10]. Аержава Аля виходу зі спаАу регулює відтворення наявного капітацу через чисті інвестиції, $J_{\text {ч }}=0,3(\omega-0,1 K)$, і використовуваного у виробництві капіталу за допомогою стимулів кон'юнктури споживчого попиту. За значеннями $\delta_{t-1}$ i $\delta_{t-2}$, віАповіАно, у 2019 і 2018 рр., у 2020 р. ринкова кон'юнктура обчислюється згіАно з формулою (19): $\Re_{\mathrm{p}}=1$. Приймається кон'юнктура ризиків і стимулів $\Re_{r s}=0,94$ за ризиком пандемії COVID-19 і стимулами Аержави щодо кон'юнктури споживчого попиту. 
Таб $и$ иц я 2

Можииві показники економіки України у 2020-2024 рр. із виходом зі спаду

\begin{tabular}{|c|c|c|c|c|c|}
\hline Показники & 2019 & 2020 & 2021 & 2022 & 2023 \\
\hline \multicolumn{6}{|c|}{ Вихідні дані } \\
\hline 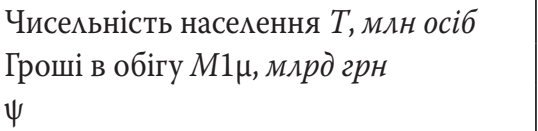 & $\begin{array}{r}41,9 \\
3970 \\
0,5\end{array}$ & $\begin{array}{r}41,7 \\
3800 \\
0,6\end{array}$ & $\begin{array}{r}41,5 \\
3900 \\
0,6\end{array}$ & $\begin{array}{r}41,3 \\
4300 \\
0,6\end{array}$ & $\begin{array}{r}41,1 \\
5280 \\
0,5\end{array}$ \\
\hline \multicolumn{6}{|c|}{ Результати моделювання за роками } \\
\hline Капітал K, млрд грн & 26969,00 & 29804,53 & 32102,18 & 4110,42 & 35849,50 \\
\hline Ринкова кон'юнктура $\Re_{\mathrm{p}}$ & 1,02 & 1 & 0,917 & 1,063 & 1,048 \\
\hline Кон'юнктура ризиків і стимулів $\mathfrak{R}_{r s}$ & 1,0 & 0,94 & 1,1 & 0,98 & 0,98 \\
\hline Працюючі у виробництві $B$, млн осіб & 11,46 & 10,77 & 10,77 & 11,22 & 11,52 \\
\hline Коефіцієнт використання капітацу $\mathrm{v}$ & 0,827 & 0,78 & 0,78 & 0,813 & 0,835 \\
\hline Працюючий капітал $K_{\text {пр }}$ млрд грн & 22537,04 & 23247,53 & 25039,70 & 27731,77 & 29932,58 \\
\hline Працюючі в економіці $N$, млн осіб & 15,28 & 14,36 & 14,36 & 14,96 & 15,36 \\
\hline Рівноважна праця $N_{0}$, млн осіб & 19,274 & 19,182 & 19,09 & 19,00 & 18,906 \\
\hline Рівень безробіття ф, \% & 20,72 & 25,14 & 24,78 & 22,79 & 15,65 \\
\hline Коефіцієнт технології $\frac{1}{\ln k_{0}}$ & 0,0701 & 0,07 & 0,0696 & 0,069 & 0,0687 \\
\hline Реальний ВВП $\Omega$, млрд грн & 3672,14 & 3771,56 & 4062,00 & $4,519,33$ & 4882,78 \\
\hline Споживчий попит $\bar{\Omega}$, млрд грн & 3730,91 & 3835,81 & 4145,22 & 4590,9 & 4955,5 \\
\hline Зміна реального ВВП $\delta, \%$ & 3,2 & $-5,11$ & 1,22 & 6,00 & 4,1 \\
\hline Виробничий Аефмятор $P_{\text {вр }}$ & 1,016 & 1,0205 & 1,0205 & 1,0158 & 1,025 \\
\hline Грошовий дефмятор $P_{\text {гр }}$ & 1,065 & 1,0428 & 1,0289 & 1,0219 & 1,038 \\
\hline Аефмятор ВВП Р & 1,082 & 1,064 & 1,05 & 1,038 & 1,04 \\
\hline 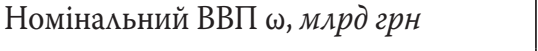 & 3974,56 & 4013 & 4265 & 4691 & 5078 \\
\hline Амортизація $A$, млрд грн & 450,74 & 464,94 & 500,8 & 554,64 & 598,66 \\
\hline АохіА $Y$, млрд грн & 3523,82 & 3548,06 & 3764,2 & 4136,36 & $4.479,34$ \\
\hline Чисті інвестиції $J_{\mathrm{u}}$, млрд грн & 431,4 & 506,4 & 528,33 & 582,73 & 625,53 \\
\hline Недоамортизація $\Delta$, млрд грн & 112,7 & 116,24 & 125,2 & 138,65 & 149,66 \\
\hline$\frac{J_{\mathrm{u}}}{\omega}, \%$ & 10,85 & 12,62 & 12,39 & 12,42 & 12,32 \\
\hline Оплата праці $W B$, млрд грн / рік & 1174 & 1183 & 1255 & 1379 & 1693 \\
\hline 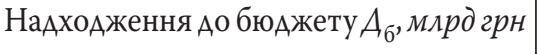 & 1174 & 1183 & 1255 & 1379 & 1693 \\
\hline $\begin{array}{l}\text { НаАходження Ао пенсійного } \\
\text { фонАу Ж, млрд грн }\end{array}$ & 375,68 & 378,56 & 401,6 & 441,28 & 541,76 \\
\hline Інвестиції до ВВП $\frac{R_{\text {вр }}}{\omega}, \%$ & 22,19 & 24,2 & 24,13 & 24,25 & 24,1 \\
\hline
\end{tabular}

Ск и а ден о за: World economic outlook database / IMF. 2018. October. URL: https://www.imf. org/ external/ pubs/ft/weo/2018/02/weodata/index.aspx; World economic outlook database / IMF. 2019. October. URL: https://www.imf.org/ external/pubs/ft/weo/2019/02/weodata/index.aspx. 
Визначається кон'юнктура споживчого попиту: $\mathfrak{R}=0,94$. За значеннями 2019 р. обчислено у 2020 р.: згіАно з формулою (17): $K_{\text {пр }}=29$ 804,53 мирА грн, $B=10,77$ млн осіб, $N=\frac{B}{0,75}$ млн осіб (формула (18)), $\mathrm{v}=0,78$ (формула (19)), $K=\mathrm{v} K_{\text {пр }}=23247,53$ мирА грн, $N_{0}=0,46 T=19,182$ млн осіб, $\frac{1}{\ln k_{0}}=\frac{1}{\ln \frac{K}{0,75 N_{0}}}=$ $=0,07, \phi=25,14 \%$. Розраховуються: $\Omega=3771,56$ млрА грн (формула (45)), $\bar{\Omega}=3835,81$ мкрА грн за формулою $(10), \delta=-5,11 \%$ (формула (16)), $P_{\text {вр }}=$ $=1,0205$ (формула (5)), $P_{\text {гр }}=1,0428, P=\frac{M 1 \mu}{\bar{\Omega}}=1,064, \omega=4013$ мкрА грн згіАно 3 формулою (1), $A=0,02 K=464,95$ млрА грн, $Y=\omega-A=3548,06$ млрА грн, $Y^{*}=W B=\frac{Y}{3}=1183$ мкрА грн, чисті інвестиції відповідно до формули (18) $J_{\mathrm{ч}}=0,3(\omega-0,1 K)=506,4$ м $\Lambda$ А грн, $\Delta=0,005 K=116,24$ м $\Lambda$ А грн тощо.

Після спаду реального ВВП у 2020 р. Ао -5,11 \% завАяки вжитим державою та НБУ заходам щодо зниження податкового тягаря, збільшення інвестицій і стримання інфцяції у 2021 р. вАасться зупинити спаА реального ВВП зі зростанням до 1,22 \% при інфмяції 5 \%. Регулювання державою інвестицій та НБУ кількісті грошей в обігу Аопоможе забезпечити зростання реального ВВП у 2022 р. Ао 6 \% при інфмяції 3,8 \% і у 2023 р. 4,1 \% при інфмяції $4 \%$.

На піАставі викцаденого можна зробити такі висновки. А૮я забезпечення виходу із спаду ВВП і стабільного розвитку економіки країни з постійним зростанням необхіАні державне регулювання розширеного віАтворення наявного й працюючого у виробництві капіталу, інфцяційне саморегулювання ринкової рівноваги через систему грошового обігу ЦБ і ставка податку на АохіА виробництва, не більша віА оптимальної ставки.

Аосягнення мети виходу зі спаду з подальшим стабільним зростанням ВВП можливе за Аержавної політики, що грунтується на фундаментальних законах економіки і права.

Центральний банк створює в економіці країни кількість грошей в обігу, яка регулює макроекономічні процеси. Неможливо змінити реальну вартість грошей збільшенням чи зменшенням суми готівки і депозитів Ао запитання, так само як і змінити суму готівки й депозитів до запитання зміною грошової бази. Нарощуючи за кредитної кризи грошову базу, ЦБ звужує креАитну базу, тобто поглиблює кредитну кризу.

Аержавний бюджет можна збалансувати за бездефіцитним споживчим попитом держави при заданій ставці зарплати або заданому дефіцитному споживчому попиту Аержави за збалансованою ставкою зарплати. Баланс економіки при збалансованому споживанні домашніх господарств тотожний безАефіцитному споживчому попиту Аержави.

\section{Список використаних Ажерек}

1. Аунаев Б. Б. БАагосостояние - труА, капитал и Аеньги: Основы теории воспроизводства. Киев : ИнтерАрук, 2013. 231 с. 
2. Аунаев Б. Б. Безынфмяционный потребитемьский спрос. Кибернетика и системный анализ. 2016. № 4. C. 103-117. URL: https://doi.org/10.1007/s10559-0169861-y.

3. Аунаев Б. Б., Кириленко А. В. Аефмяционное регулирование рыночного равновесия. Кибернетика и системный анализ. 2018. № 2. C. 95-108. URL: https://doi. org/10.1007/s10559-018-0027-у.

4. Гэмбл Э. Кризис без конца? Крах западного процветания : пер. с англ. Москва : ИзАат. Аом ВШЭ, 2018. 304 с.

5. Аунаев Б. Б. Аинамика экономических цикцов. Кибернетика и системный анализ. 2017. № 2. С. 146-162. URL: https://doi.org/10.1007/s10559-017-9929-3.

6. Ротбард М. Великая депрессия в Америке : пер. с англ. Москва : ИРИСЭН : Мысль, 2012. 522 с.

7. Стиглии, Аж. Крутое пике: Америка и новый экономический порядок после глобацьного кризиса : пер. с англ. Москва : Эксмо, 2011. 512 с.

8. Єбименко T. І. Фіскальна та монетарна безпека національної економіки ; АННУ “АкаА. фін. управління”. Київ, 2016. 447 с.

9. Сакс А., Ааррен Ф. Макроэкономика. Гцобацьный подход : пер. с англ. Москва : Аемо, 1999. 848 с.

10. Аунаев Б. Б. Оптимизация ставки налога на доход производства. Кибернетика и системный анализ. 2019. № 3. С. 99-111. URL: https://doi.org/10.1007/s10559-01900150-7.

11. Горбачук В. М. Макроекономічні методи. Київ : ААьтерпрес, 1999. 263 с.

12. Горбачук В. М. Макроекономічні методи: теорії та застосування. Київ : Кий, 2000. 271 c.

13. Горбачук В. М. Про взаємозв'язок між реацьною грошовою масою, бюАжетним Аефіцитом і рівнем оподаткування. Аоповіді НАН України. 1999. С. 97-101.

14. Зведені національні рахунки за 2018 рік / Аержавна служба статистики України. URL: http://www.ukrstat.gov.ua.

15. Виконання Аержавного бюАжету України. 2019 / Мінфін. 2021. URL: https:// index.minfin.com.ua/finance/budget/gov/2019.

16. World economic outlook database / IMF. 2018. October. URL: https://www.imf. org/external/pubs/ft/weo/2018/02/weodata/index.aspx.

17. World economic outlook database / IMF. 2019. October. URL: https://www.imf. org/external/pubs/ft/weo/2019/02/weodata/index.aspx.

\section{References}

1. Dunaev, B. B. (2013). Well-Being: Labor, Capital, and Money. Fundamentals of the Reproduction Theory. Kyiv: Interdruk [in Russian].

2. Dunaev, B. B. (2016). Non-Inflationary Consumer Demand. Cybernetics and Systems Analysis, 52 (4), 103-117. DOI: 10.1007/s10559-016-9861-y [in Russian].

3. Dunaev, B. B., \& Kirilenko, L.V. (2018). Deflationary Regulation of Market Equilibrium. Cybernetics and Systems Analysis, 54 (2), 95-108. DOI: 10.1007/s10559-018-0027-y [in Russian].

4. Gamble, E. (2018). An Endless Crisis? The collapse of Western prosperity. Moscow: Publishing House of the Higher School of Economics [in Russian].

5. Dunaev, B. B. (2017). Dynamics of Economic Cycles. Cybernetics and Systems Analysis, 53 (2), 146-162. DOI: 10.1007/s10559-017-9929-3 [in Russian].

6. Rothbard, M. (2012). The Great Depression in America. Moscow: IRISEN: Mysl [in Russian]. 
7. Stiglitz, J. (2011). Steep Dive: America and the New Economic Order after the Global Crisis. Moscow: Eksmo [in Russian].

8. Iefymenko, T. (2016). Fiscal and Monetary Security of National Economy. Kyiv: SESE "The Academy of Financial Management" [in Ukrainian].

9. Sachs, D., \& Larren, F. (1999). Macroeconomics. Global approach. Moscow: Delo [in Russian].

10. Dunaev, B. B. (2019). Optimization of Production Income Tax Rate. Cybernetics and Systems Analysis, 55 (3), 99-111. DOI: 1007/s10559-019-00150-7 [in Russian].

11. Horbachuk, V. M. (1999). Macroeconomic methods. Kyiv: Alterpress [in Ukrainian].

12. Horbachuk, V. M. (2000). Macroeconomic methods: theories and applications. Kyiv: Kyi [in Ukrainian].

13. Horbachuk, V. M. (1999). About the relationship between real money supply, budget deficit and the level of taxation. Reports of the National Academy of Sciences of Ukraine, 97-101 [in Ukrainian].

14. State Statistics Service of Ukraine. (n. d.). Consolidated national accounts for 2018. Retrieved from http://www.ukrstat.gov.ua [in Ukrainian].

15. Minfin. (2021). Execution of the state budget of Ukraine. Retrieved from https:// index.minfin.com.ua/finance/budget/gov/2019 [in Ukrainian].

16. IMF. (2018, October). World economic outlook database. Retrieved from https:// www.imf.org/ external/ pubs/ft/weo/2018/02/weodata/index.aspx.

17. IMF. (2019, October). World economic outlook database. Retrieved from https:// www.imf.org/ external/ pubs/ft/weo/2019/02/weodata/index.aspx. 